\title{
Mediterranean Syllidae (Annelida: Polychaeta) revisited: biogeography, diversity and species fidelity to environmental features
}

\author{
Luigi Musco*, Adriana Giangrande \\ Laboratorio di Zoologia e Simbiosi, DiSTeBA, Università di Lecce, Via Prov.le Lecce-Monteroni, 73100 Lecce, Italy
}

\begin{abstract}
The species diversity of Syllidae (Annelida: Polychaeta) on different coastlines within the Mediterranean Basin was analysed, including along the Salento Peninsula (Italy), which is thought to play a crucial role as a crossroads between different biogeographic areas. Analysis of biogeography, the assignment of species into 6 bioclimatic categories, a novel method to assess intermatrix correlation significance and the correlation between species distribution, and some environmental variables provided relevant tools to investigate the influence of a suite of ecological and historical factors on syllid distribution. Data showed that Syllidae could be considered a useful taxon for biogeographic speculations, even though bioclimatic and environmental analyses appeared significantly more informative. The Salento Peninsula revealed an affinity with some eastern Mediterranean coastlines. Syllid distribution suggested the existence of an 'Atlantism' gradient, decreasing eastwards and possibly corresponding to a temperature gradient when bioclimatic categories were analysed. In contrast to previous results, the Eastern and Western Basins did not show great differences in species diversity. The observed differences could, in part, be due to an 'author effect', due to the differing taxonomic updating of the available faunistic lists. Syllidae were found to be effective faunistic and ecological indicators, able to characterize different areas inside the Mediterranean Sea; thus, the present results could be used to stimulate further research on different aspects of the family.
\end{abstract}

KEY WORDS: Polychaeta $\cdot$ Syllidae $\cdot$ Mediterranean $\cdot$ Biogeography $\cdot$ Species diversity $\cdot$ Multivariate analysis $\cdot$ Taxonomic updating $\cdot$ Water temperature $\cdot$ Salinity

Resale or republication not permitted without written consent of the publisher

\section{INTRODUCTION}

\section{The Mediterranean Basin}

The Mediterranean Sea is one of the widest marine warm-temperate regions in the world, forming a sort of climatic and biogeographic crossroads between tropical and temperate seas. This area is characterized by high biodiversity, which has probably been caused by its complex evolutionary history through the Tertiary and the post-Pliocene diversity pump from the Atlantic (Bianchi \& Morri 2000, Bouillon et al. 2004). As a result, the present marine inventory is composed of species belonging to several biogeographic categories, with dominance of the Atlanto-Mediterranean (Pérès 1985). Inside the whole basin it is possible to distinguish 3 large ecologically and historically different areas (the
Western and Eastern Basins, and the Adriatic Sea). A further subdivision of these areas recognises a total of 10 different biogeographic zones. The most 'typical' endemic fauna occurs in the central part of the basin (Bianchi \& Morri 2000). Most of the past changes (e.g. the arrival of new species) occurred throughout the Gibraltar Channel, influencing the Western Basin more than the Eastern one. The Alboran Sea exhibits a stronger Atlantic influence, while the Levant Sea experiences influx from the Red Sea via the Suez Canal (Lessepsian migration) (Por 1978, 1989) and, therefore, shows a more sub-tropical character. Historical reasons are, however, just one side of the 'evolutionary laboratory'; the other side is strictly ecological: seasonality is one of the potential key characters for the coexistence of a high number of species (Coma et al. 2000). Surface temperatures range between 11 and 
$13^{\circ} \mathrm{C}$ (with extremes of 4 to $5^{\circ} \mathrm{C}$ in the Gulf of Trieste) in winter and 25 to $30^{\circ} \mathrm{C}$ in summer, determining coldtemperature to warm-temperature conditions in the cold season and tropical conditions in the warm season (Bouillon et al. 2004). The complex Mediterranean geography amplifies the ecological differences of its major divisions: the Western Basin is more influenced by Atlantic water features; the Eastern Basin has a more southern location and is more confined, with a higher evaporation rate. Moreover, within this area, the Aegean Sea shows some differences due to shallower water, low salinity and temperature values, and furthermore an influence of water from the Black Sea (Arvanitidis et al. 2002). The Apulian Ionian Basin, geographically included in the Eastern Basin, is characterized by high water temperature and dominance of deep water habitats. On the other hand, the South Apulian Adriatic coast shares similar ecological features with the Ionian Basin, thus differing from the North Adriatic coast. There, the large input of freshwater from the land, the shallow waters and the absence of 'tropicality' indicate a typical North Atlantic ecological regime. This is the reason why some authors prefer not to consider the Adriatic Sea as a single biogeographic unit (Bianchi \& Morri 2000).

The Mediterranean Basin, although representing only $0.82 \%$ in surface area and $0.32 \%$ in volume of the world's oceans, hosts a large number of worldwide macroscopic marine organisms (from 4 to $18 \%$ of benthic species and about $9 \%$ of polychaetes) (Bianchi \& Morri 2000, Arvanitidis et al. 2002). This richness is surely linked to the deep-rooted Mediterranean faunistic tradition, but also to the peculiar ecological features and the geological history of the basin. Up to now, about 8000 macroscopic marine invertebrates have been described for the whole Mediterranean Basin, $87 \%$ of which were found in the Western Basin, $48.9 \%$ in the Adriatic and $43.1 \%$ in the Eastern Basin (Morri et al. 1999). The Western Basin also includes $77 \%$ of the endemic species, but this high percentage could be influenced by the fact that it has been studied longer and more thoroughly (Bouillon et al. 2004).

\section{Mediterranean syllids}

Syllidae is one of the most diverse families within Polychaeta (Annelida), numbering about 667 taxa, distributed in a large array of habitats, especially in the littoral fringe. Syllidae has already been successfully utilized in biogeographic analysis within the Mediterranean Sea (San Martín 1984), revealing that the basin could be divided into 2 zones based on the presence or absence of syllid tropical forms: a northern zone (France, Gulf of Naples, Ionian and Adriatic Seas) and a southern zone (Spain, North Africa, Sicily and Israel). Since the 1990s, a great deal of work has been devoted to Mediterranean syllids, readdressing part of the lack of knowledge that was underlined as one of the main problems in understanding patterns of their distribution (Castelli et al. 1995, Ergen \& Çinar 1997, Simboura \& Nicolaidou 2001, Çinar \& Ergen 2002, 2003, Çinar et al. 2003). However, increasing taxonomic knowledge would require frequent faunistic updating of syllid inventories; this would be particularly desirable in some well-known, but presently poorly studied, areas (e.g. northern Adriatic Sea and Israeli coastline). Furthermore, some areas, such as the French Mediterranean and northern African coastlines, need to be investigated in more detail, because syllid inventories in these areas are presently very poor, especially if compared to the knowledge on other polychaete families.

Recent research on syllid diversity along the Ionian and Adriatic coasts of the Salento Peninsula (Apulia, southern Italy) has increased the number of recorded species in the area by $90 \%$, and added 1 species new to the science (Sphaerosyllis boeroi), another species new to the Mediterranean area (Syllis alosae), 3 species new to the Eastern Basin, 9 species new to the Italian coast and 40 species new to the Adriatic Sea (Gherardi et al. 2001, Fraschetti et al. 2002, Giangrande et al. 2003, 2004, Corriero et al. 2004, Musco et al. 2004, 2005). The polychaetes of the Sabellidae family also revealed the peculiarity of this coastline, with the discovery of some species distributed only in the Eastern Mediterranean (Giangrande \& Montinaro 1989). This area is, in fact, considered a biogeographical crossroads between the Western and Eastern Basins. Its Ionian coast shows subtropical-like features, in particular around Porto Cesareo, which is an area characterized by a unique faunistic composition. A similar pattern has been observed along the South Adriatic coast (Sarà 1967, Parenzan 1983).

According to Fauchald (1984) polychaete species distribution is more influenced by ecological features than historical (biogeographic) ones. Some recent work has also showed that species diversity, abundance and distribution of Syllidae are particularly influenced by several environmental features (Fraschetti et al. 2002, Giangrande et al. 2003, 2004, Musco et al. 2004).

In the present paper, a review of the diversity of syllids in the Mediterranean area is attempted, with a comparison of species inventories reported from different coastlines from: (1) faunistic, (2) biogeographic and (3) bioclimatic points of view. A correlation between the present syllid distribution and (4) taxonomic updating and some environmental parameters is also proposed. 
Fig. 1. Map of the study area. Dots show the analysed coasts (SP: Spanish; NWI: North Western Italian; TU: Turkish Aegean; CY: Cypriot; GR: Greek Aegean; IS: Israeli; ES: Eastern Sicilian; SI: Ionian Salento; SA: Adriatic Salento; NA: North Adriatic) and represent the geo-referenced points where environmental parameters have been calculated using the GDEM (1998) historical database

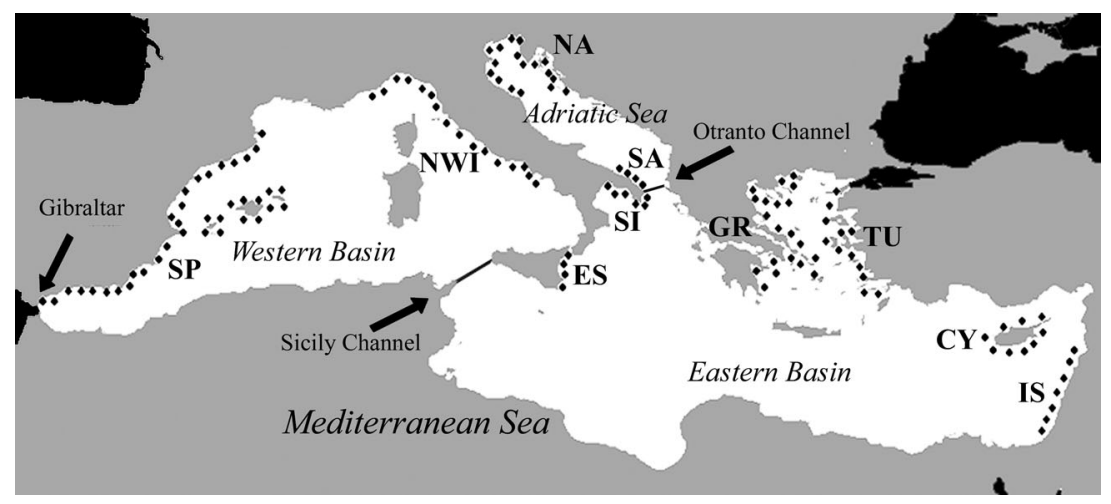

\section{MATERIALS AND METHODS}

Study area and faunistic data. Literature data relevant to the family Syllidae were reviewed in order to infer the syllid distribution along those Mediterranean coastlines for which a check-list or, alternatively, exhaustive, updated faunistic inventories are available (Fig. 1). In the Western Mediterranean area (extending from Gibraltar Channel to Sicily Channel) we considered: (1) the Spanish Mediterranean (guideline checklist: San Martín 2003; additional records: Sardà 1991, Tena et al. 2000) and (2) North Western Italian coasts (guideline check-list: Castelli et al. 1995; additional records: Somaschini \& San Martín 1994, 1997, Badalamenti et al. 1999, Licher 1999). In the Eastern Mediterranean area (from Sicily Channel eastwards) the areas studied were: (3) the Turkish Aegean (faunistic inventories: Ergen \& Çinar 1997, Çinar \& Ergen 2002), (4) the Cypriot area (faunistic inventories: Çinar \& Ergen 2003, Çinar et al. 2003, Musco et al. 2005), (5) the Greek Aegean (guideline check-list: Simboura \& Nicolaidou 2001; additional records: Arvanitidis 2000), (6) the Israeli Mediterranean (faunistic inventories: Fauvel 1955, 1957, Ben-Ehliau 1977a,b, 1995, Goren 1979, Fishelson \& Haran 1986, Ben-Ehliau \& Fiege 1995), (7) Eastern Sicilian coasts (faunistic inventories: Cantone 1971, 2001, Cantone \& Fassari 1980, Cantone et al. 1979,2003 ) and (8) the Ionian coast of Salento (faunistic inventories: Gherardi et al. 1993, 2001, Corriero et al. 2004, Musco et al. 2005). Finally, in the Adriatic Sea (from Otranto Channel northwards), we considered: (9) the Adriatic coast of Salento (faunistic inventories: Fraschetti et al. 2002, Giangrande et al. 2003, 2004) and (10) the North Adriatic (guideline check-list: PozarDomac 1978; additional records: Marenzeller 1874, Banse 1959, Katzmann 1972, Castelli et al. 1995).

In addition, other records from non-analysed areas were included in order to obtain a faunistic comparison between the Eastern and Western Basins and the complete syllid inventories of the whole Mediterranean Basin (Fauvel 1923, 1937, Pérès 1954, Laubier 1966,
Bellan 1991, Licher 1999, Nogueira \& San Martín 2002, Çinar \& Ergen 2003, Çinar et al. 2003).

Environmental data. Since faunistic data were represented by a several-year study stratification (at least since the 19th century), environmental parameters relative to the study areas were necessarily based on long-time averages. Monthly water temperature and salinity values were calculated using the Mediterranean historical database of the generalized digital environmental model (GDEM) of the US Naval Oceanographic Office (NAVOCEANO 1998) (available from https://128.160.23.42/gdemv/gdemv.html). Using a coordinated system grid (pass $0.5^{\circ}$ ) the Mediterranean Basin was divided into polygons. For each polygon (the ones closer to the coastlines analysed) 1 single point was randomly chosen and geo-referenced; resulting latitude/longitude coordinates were used to extract temperature and salinity values from the GDEM database. Available data from the sea surface to $30 \mathrm{~m}$ depth (usual bathymetric syllid home-range; San Martín 2003) were averaged in order to obtain monthly mean values per each random point of an area; hence, monthly mean values per analysed coastline were calculated (Table 1).

Table 1. Annual minimum (min.) and maximum (max.) mean temperature and salinity (GDEM 1998), and taxonomic updating index (T.U.I.) for the analysed Mediterranean coastlines. For abbreviations see Fig. 1

\begin{tabular}{|lrrrrr|}
\hline \multirow{2}{*}{ Coastline } & \multicolumn{2}{c}{ Temperature $\left({ }^{\circ} \mathrm{C}\right)$} & \multicolumn{2}{c}{ Salinity $(\%)$} & \multirow{2}{*}{ T.U.I. } \\
& min. & max. & min. & max. & \\
\hline SP & 13.69 & 22.44 & 37.35 & 37.65 & 0.994 \\
NWI & 13.38 & 21.97 & 37.88 & 38.07 & 0.931 \\
TU & 15.17 & 22.01 & 37.73 & 38.89 & 0.977 \\
CY & 16.66 & 24.76 & 38.94 & 39.20 & 0.996 \\
GR & 14.33 & 23.35 & 37.65 & 38.58 & 0.994 \\
IS & 16.86 & 27.36 & 38.91 & 39.17 & 0.747 \\
ES & 14.38 & 23.95 & 37.94 & 38.18 & 0.758 \\
SI & 13.77 & 24.25 & 38.14 & 38.35 & 0.975 \\
SA & 13.01 & 23.06 & 38.25 & 38.25 & 0.994 \\
NA & 9.99 & 21.72 & 36.97 & 37.19 & 0.687 \\
& & & & & \\
\hline
\end{tabular}


Taxonomic updating. As already mentioned, the presently analysed inventories of species were derived from different datasets developed in different years. Due to increasing knowledge (e.g. new species are described almost every year) the faunistic dataset is continuously changing. In order to weight the inventories' taxonomic updating, the whole set of 176 syllid species recorded up to now in the Mediterranean Sea was chronologically ordered, considering the year of species discovery from the earliest (Syllis armillaris) to the most recently described (Sphaerosyllis boeroi). Then, the percentage of known species at the time of publication of the analysed guideline check-lists was determined, and this relative value (ranging from 0 to 1) was the 'Taxonomic Updating Index' (T.U.I.) of the analysed coastline inventory. For those analysed coastlines lacking a guideline checklist, the mean T.U.I. value of the available faunistic inventories was calculated (Table 1).

Analyses. To obtain faunistic, biogeographic and bioclimatic comparisons between the analysed waste, a presence-absence matrix (176 species by 10 coastlines) was performed (Appendix 1; see www.intres.com/articles/suppl/m304p143_app.pdf). Differences in species composition among coasts were represented in a similarity matrix based on the Bray-Curtis similarity index and analysed by Cluster Analysis (PRIMER, Plymouth Marine Laboratory) (Clarke 1993).

Species were also arranged in categories according to their worldwide biogeographic distributions (e.g. San Martín 1984, Arvanitidis et al. 2002): (1) cosmo-

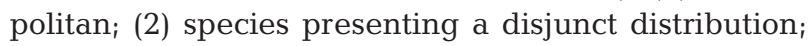
(3) circum-tropical; (4) Indo-Atlantic-Mediterranean (species not included in the cosmopolitan category in order to avoid a loss of biogeographic information); (5) Indo-Mediterranean (probably Lessepsian migrants); (6) amphi-Atlantic; (7) Atlantic-Mediterranean; and (8) endemic Mediterranean.

Another literature-based classification of the species was made according to their worldwide distribution in or between the different climatic zones outside the Mediterranean area (bioclimatic distribution): (1) Cold = species distributed in cold waters (Arctic, sub-Arctic, Antarctic, sub-Antarctic species), (2) Temperate-cold $=$ species distributed in temperate cold waters (mainly European North Atlantic species), (3) Temperate $=$ species distributed in temperate waters (mainly Iberian Atlantic species), (4) Temperatewarm $=$ species distributed in temperate warm waters (subtropical species or those widely distributed between tropical and temperate zones), (5) Warm = species distributed in warm waters (inter-tropical species) and (6) Eurythermic = eurythermic species (see Appendix 1 for references). The null hypothesis assumes that the above-mentioned categories (both bioclimatic and biogeographic) were arranged between analysed Mediterranean coasts without any recognisable distributional pattern. In this context, in order to avoid any a priori statement about the "bioclimatic features' of the different analysed zones, the endemic Mediterranean forms were included in the temperate category. Relative frequency of the abovementioned groups was calculated for each coast (Table 2), obtaining both a biogeographic matrix ( 8 variables by 10 samples) and a bioclimatic matrix (6 variables by 10 samples). Factors mainly contributing to dissimilarity between pairs of coasts were identified by SIMPER routine; in both cases affinities

Table 2. Percentages of the species biogeographic (BG) groupings (c: cosmopolitan; d: disjunct distribution; ct: circum-tropical; iam: Indo-Atlantic-Mediterranean; im: Indo-Mediterranean; aa: amphi-Atlantic; am: Atlantic-Mediterranean; m: endemic Mediterranean) and of the species bioclimatic (BC) groupings (C: cold; TC: temperate-cold; T: temperate; TW: temperate-warm; W: warm; E: eurythermic) on the analysed coasts (for abbreviations see Fig. 1)

\begin{tabular}{|c|c|c|c|c|c|c|c|c|c|c|}
\hline & SP & NWI & TU & $\mathrm{CY}$ & GR & IS & ES & SI & SA & NA \\
\hline \multicolumn{11}{|l|}{ BG } \\
\hline $\mathrm{C}$ & 0.170 & 0.186 & 0.256 & 0.250 & 0.229 & 0.436 & 0.400 & 0.236 & 0.256 & 0.317 \\
\hline d & 0.178 & 0.161 & 0.209 & 0.179 & 0.135 & 0.154 & 0.160 & 0.139 & 0.128 & 0.117 \\
\hline ct & 0.044 & 0.025 & 0.047 & 0.048 & 0.052 & 0.103 & 0.060 & 0.042 & 0.051 & 0.017 \\
\hline iam & 0.044 & 0.059 & 0.047 & 0.060 & 0.052 & 0.051 & 0.080 & 0.069 & 0.051 & 0.050 \\
\hline im & 0.022 & 0 & 0 & 0 & 0 & 0 & 0 & 0 & 0 & 0 \\
\hline aa & 0.141 & 0.119 & 0.151 & 0.119 & 0.104 & 0.103 & 0.100 & 0.139 & 0.179 & 0.100 \\
\hline $\mathrm{am}$ & 0.244 & 0.314 & 0.221 & 0.250 & 0.365 & 0.128 & 0.180 & 0.278 & 0.256 & 0.350 \\
\hline $\mathrm{m}$ & 0.156 & 0.136 & 0.070 & 0.095 & 0.062 & 0.026 & 0.020 & 0.097 & 0.077 & 0.050 \\
\hline \multicolumn{11}{|l|}{ BC } \\
\hline C & 0 & 0.008 & 0 & 0 & 0.010 & 0 & 0 & 0 & 0 & 0.017 \\
\hline $\mathrm{TC}$ & 0.104 & 0.118 & 0.047 & 0.071 & 0.167 & 0.128 & 0.120 & 0.083 & 0.077 & 0.233 \\
\hline $\mathrm{T}$ & 0.348 & 0.356 & 0.291 & 0.298 & 0.281 & 0.077 & 0.120 & 0.333 & 0.295 & 0.200 \\
\hline TW & 0.289 & 0.254 & 0.337 & 0.345 & 0.260 & 0.410 & 0.340 & 0.333 & 0.372 & 0.183 \\
\hline W & 0.044 & 0.008 & 0.012 & 0.036 & 0.021 & 0.051 & 0.020 & 0.014 & 0.026 & 0 \\
\hline E & 0.215 & 0.254 & 0.314 & 0.250 & 0.260 & 0.333 & 0.400 & 0.236 & 0.231 & 0.367 \\
\hline
\end{tabular}


among coasts were represented by a similarity matrix based on the Bray-Curtis similarity index and analysed using Cluster Analysis (PRIMER, Plymouth Marine Laboratory) (Clarke 1993).

Relating different matrices derived from the same dataset. In order to test the concordance between the faunistic pattern and the bioclimatic and biogeographic grouping of the same dataset, frequency matrices were separately compared to the presenceabsence species matrix, calculating the respective Spearman rho-values (RELATE routine, PRIMER, Plymouth Marine Laboratory) (Clarke 1993). However, in this case, we did not really use the significance of the RELATE test, as much as the actual relative values of the rho- coefficient. The rho-value has been considered a useful measure of the concordance between the information held in these groupings of the same data. Due to the absence of a significance test convincingly stressing differences between the rho-values for the 2 comparisons, we used a random re-arrangement of the original species matrix, in which the samples were kept as they were. The species were pooled into 8 groups (in the biogeographic case), with the same number of species falling into each group as for the real biogeographic divisions, but the species selected to go into these groups was chosen at random from the set of 176 species recorded. In other words, the rows of the original matrix were randomly re-arranged while keeping the biogeographic labels (BG in Appendix 1) fixed. We calculated Spearman's rho for the resulting randomly aggregated frequency matrix (Bray-Curtis similarities) according to the original 176 species (Bray-Curtis similarities), then we repeated the procedure 50 times, obtaining a rho-value for each time. The same routine was applied with the bioclimatic groupings (Clarke pers. comm.).

To obtain statistical evidence on whether the biogeographic and bioclimatic groupings were just by chance (or not), we tested the significance of the actual rho versus the mean of the 50 randomly calculated rhovalues $\left(\mathrm{rho}_{\mathrm{rnd}}\right)$ by a $t$-test: $t_{(n-1)}=\left(\mathrm{rho}-\mathrm{rho}_{\mathrm{rnd}}\right)$ \{sqrt [var $\left.\left.(n+1) n^{-1}\right]\right\}^{-1}$.

BIOENV analysis. In order to detect possible reasons for the distributional pattern of Mediterranean syllids, a comparison between the similarity matrix based on the original 176 species (Bray-Curtis similarities) and the normalized matrix of environmental parameters (annual minimum and maximum water temperature and annual minimum and maximum salinity) and the percentage values representing the taxonomic updating of species inventories was performed and tested by the standard BIOENV routine; correlations between parameters were analysed by a Draftsman plot routine (PRIMER, Plymouth Marine Laboratory) (Clarke 1993).

\section{RESULTS}

\section{Species diversity and biogeography of Mediterranean syllids}

A total of 176 syllid species was listed for the whole Mediterranean Sea (Appendix 1; www.int-res.com/ articles/suppl/m304p143_app.pdf); 161 species were reported to be present in the Western Basin (91\%), 144 in the Eastern Basin (81\%) and 100 in the whole Adriatic Sea (56\%). Considering these 3 geographic areas, the Atlantic-Mediterranean species were more abundant, while the Indo-Mediterranean elements were present only in the Western Basin, where the largest number of endemic forms was also observed. Relatively, the number of cosmopolitan species was higher in the Adriatic (Fig. 2a). The bioclimatic composition was similar in the 3 areas, with a decrease of the temperate category in the Adriatic Sea, coupled with an increase in eurythermic species (Fig. 2c).

Fig. 3 shows the distribution of biogeographic (Fig. 3a) and bioclimatic (Fig. 3b) categories on the coastlines under analysis. The Indo-Mediterranean forms were recorded only along the Spanish Mediterranean coast; this coast together with the North Western Italian showed the highest percentages of endemic forms and the lowest percentages of cosmopolitan forms. These latter were found to be very abundant in the North Adriatic and predominant on Israeli and Eastern Sicilian coasts, where, in contrast, endemic and Atlantic-Mediterranean forms were scarce. This last category was predominant on the Greek Aegean, North Western Italian and North Adriatic coasts. As far as the bioclimatic categories were concerned, Israeli, Eastern Sicilian and North Adriatic coasts were the ones that differentiated most from the rest, being characterized by the highest percentage of eurythermic species; moreover, the Israeli coast showed the highest percentages of warmer categories (temperate-warm and warm), while the North Adriatic coast was characterized by the highest percentage of colder categories (temperate-cold and cold), followed by the Greek Aegean coast. Finally, both the coasts of Salento, together with the Turkish Aegean and Cyprus, showed high percentages of temperate-warm, the lowest percentages of temperate-cold and the complete absence of species belonging to the cold category.

\section{Cluster analysis}

The analysis of the species composition is shown in Fig. 4a. Two main clusters were recognisable: one consisting of the North Adriatic coast, together with Israeli and Eastern Sicilian coasts, and a second one consist- 

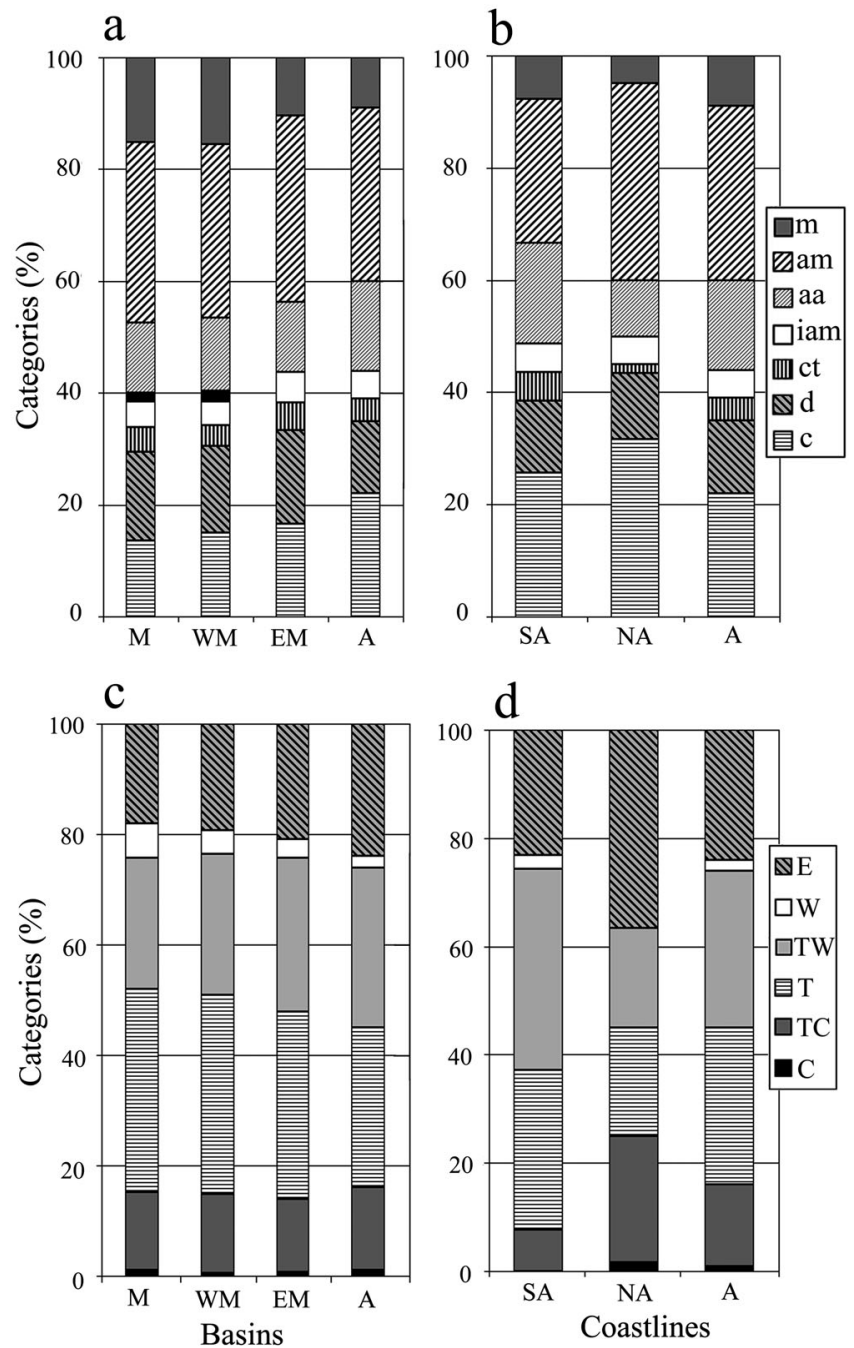

Fig. 2. $(\mathrm{a}, \mathrm{c})$ Category composition affinities in the main geographic basins (M: whole Mediterranean Basin; WM: Western Basin; EM: Eastern Basin; A: Adriatic Sea). (b, d) Finer subdivision of the Adriatic Basin coastlines (SA: South Adriatic; NA: North Adriatic). (a, b) Biogeographic categories (m: endemic; am: Atlantic-Mediterranean; aa: amphi-Atlantic; im: Indo-Mediterranean; iam: Indo-Atlantic-Mediterranean; ct: circum-tropical; d: disjunct distribution; c: cosmopolitan). (c, d) Bioclimatic categories (E: eurythermic; W: warm; TW: temperate-warm; T: temperate; TC: temperate-cold; C: cold)

ing of the remaining coasts. Within this second cluster a first separation occurred between the Greek Aegean and the other coasts, and a second, between the cluster represented by the western coasts (Spanish and North Western Italian) and the remaining ones (the 2 coasts of Salento, Turkish Aegean and Cyprus). Similar patterns were obtained when coasts were analysed utilizing both biogeographic (Fig. 4b) and bioclimatic (Fig. 4c) categories. In both analyses the Israeli and Eastern Sicilian coasts clustered apart from the 2 main clusters containing the first (Ionian and Adriatic Salento, Turkish Aegean and Cyprus) and second
(Spanish and North Western Italian) coasts. The main differences between the 3 models involved the positions of the Greek and North Adriatic coasts. In particular, in the biogeographic model, these 2 coasts clustered together close to the main cluster containing the 2 coasts of Salento, the Turkish Aegean, Cyprus and the Spanish and North Western Italian coasts, while, in the bioclimatic model, the North Adriatic showed the lowest similarity with the other coasts and Greece clustered close to the western coasts.

Considerable differences in the biogeographic (Fig. 2b) and bioclimatic (Fig. 2d) patterns between the 2 Adriatic coasts were also observed. They showed the lowest similarity within the analysed coasts (BrayCurtis similarity 69.10) from a bioclimatic point of view (SIMPER analysis revealed that temperate-warm, temperate-cold and eurythermic species accounted for $77.80 \%$ of the dissimilarity), while, in the biogeographic grouping, although the same sectors showed a higher similarity (Bray-Curtis similarity 84.61), the Adriatic Salento was more similar to the Ionian
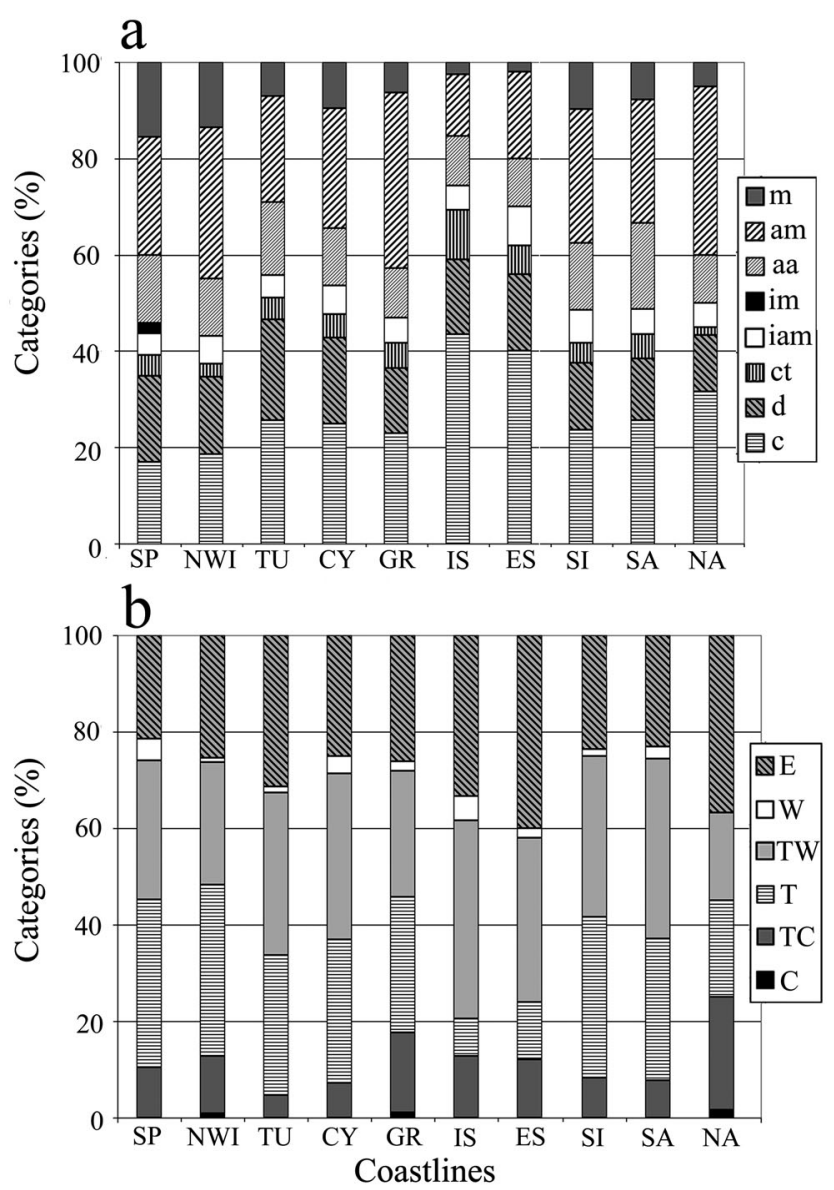

Fig. 3. Comparison between category composition among the analysed coasts (for abbreviations see Fig. 1). (a) Biogeographic categories (for abbreviations see Table 2). (b) Bioclimatic categories (for abbreviations see Table 2) 
a

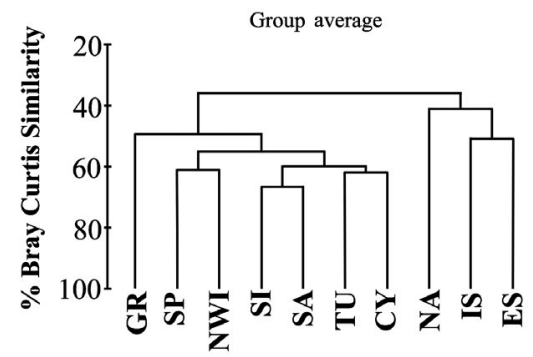

b

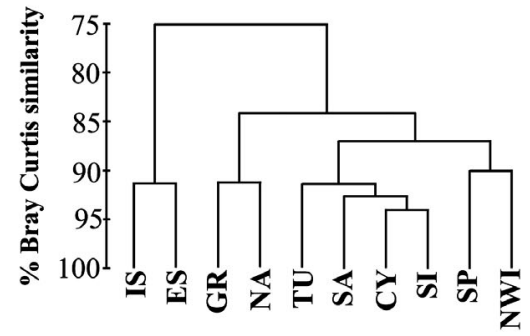

$\mathrm{C}$

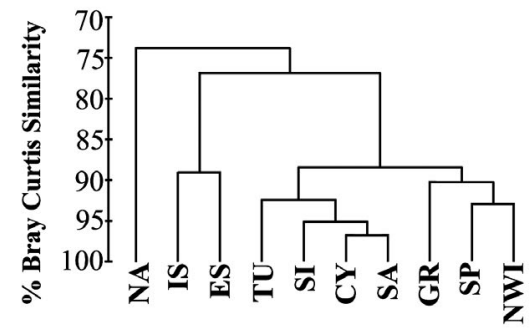

Fig. 4. Cluster analyses of the examined coastlines (for abbreviations see Fig. 1) based on: (a) species, (b) biogeographic and (c) bioclimatic similarity matrices

Salento, Greece, Cyprus, Turkey and Spain (Bray-Curtis similarity ranging from 84.95 to 92.9 ) than the North Adriatic coast (SIMPER analysis revealed that AtlanticMediterranean, amphi-Atlantic and cosmopolitan categories accounted for $75.83 \%$ of the dissimilarity).

\section{Relating different matrices derived from the same dataset}

Spearman's rho was obviously high for both analyses, representing comparisons between different matrices derived from the same dataset $(\mathrm{rho}=0.813$ for the correlation between presence-absence matrix and biogeographic categories and rho $=0.885$ for bioclimatic categories). However $t$-test analyses (random rho versus actual rho-values) revealed the significance of the correlation between the species matrix and the bioclimatic categories matrix $\left(t_{(49)}=2.2904 ; \mathrm{p}<0.01\right)$, on the one hand, and the non-significance of the correlation between the species matrix and the biogeographic categories matrix $\left(t_{(49)}=1.3956 ; \mathrm{p}>0.05\right)$, on the other hand.

\section{BIOENV analysis}

The correlation between species matrix and parameters (environmental data and T.U.I.; Table 1) was significantly high (rho $=0.806$; significance level of sample statistic: $0.5 \%$ ). Spearman's rank correlation coefficients indicated that the combination of parameters providing the highest value were the maximum annual water temperature and taxonomic updating (Table 3). High rho-values were also obtained in the combination of these 2 same parameters with minimum annual water temperature (second best result; rho $=0.739$ ) and with maximum annual salinity (third best result; rho $=0.733$ ). However, the relative position of environmental parameters in the best results' sequence was of secondary importance. Results from the Draftsman plot routine showed, in fact, low correlation between environmental parameters and taxonomic updating (rho-values ranging from -0.22 to 0.29 ), but high correlation within environmental parameters (rho-values ranging from 0.67 to 0.92 ).

\section{DISCUSSION AND CONCLUSIONS}

\section{Species diversity and biogeographic patterns}

Syllids confirm the already stated high invertebrate species richness of the Mediterranean Basin (Bianchi \& Morri 2000, Arvanitidis et al. 2002). They represent, in fact, $26.5 \%$ of the syllid species worldwide, corresponding to $68 \%$ of the genera up to now estimated for the entire world (San Martín 2003). Notwithstanding the existence of a slightly decreasing west-east gradi-

Table 3. Best results from BIOENV routine (PRIMER, Plymouth Marine Laboratory) based on Spearman's correlation between species-based resemblance matrix (Bray-Curtis similarity) and normalized parameter matrix (Euclidean distance). The variables (a: annual minimum mean temperature; b: annual maximum mean temperature; $\mathrm{c}$ : annual minimum mean salinity; d: annual maximum mean salinity; e: taxonomic updating index) associated to Spearman's correlation coefficient (rho) are reported

\begin{tabular}{|ll|}
\hline Variables & Rho \\
\hline b, e & 0.806 \\
a, b, e & 0.739 \\
c, e & 0.733 \\
e & 0.726 \\
b, d, e & 0.715 \\
a, e & 0.710 \\
b, c, e & 0.708 \\
d, e & 0.684 \\
a, b, c, e & 0.680 \\
a, b, d, e & 0.659 \\
\hline
\end{tabular}


ent of species diversity, our data document a richness of the Eastern Mediterranean species that is higher than expected. This phenomenon, already observed for the whole class (Arvanitidis et al. 2002), is most probably caused by the recent above-mentioned increase in research along the Eastern Mediterranean coast. Moreover, our data document a richness of Adriatic species (100) that is slightly higher than the 93 recently reported (Cantone 2003) and confirm Syllidae to be the most diverse polychaete family in this basin.

The endemism rate $(15 \%)$ of Mediterranean syllids appears lower than that estimated for other invertebrate groups (Bianchi \& Morri 2000), but similar to the $19 \%$ recently calculated for polychaete taxon (Arvanitidis et al. 2002), following the general trend of the class. Similar values to those found by Arvanitidis et al. (2002) were observed for other categories (amphi-Atlantic, IndoMediterranean, Atlantic-Mediterranean) and also for cosmopolitan syllids. In the present paper the more comprehensive cosmopolitan category proposed by the above-mentioned authors was split into 4 categories (cosmopolitan, circum-tropical, Indo-Atlantic-Mediterranean and species presenting a disjunct distribution) and the sum of the 4 categories was very much the same (39\% vs $41 \%$ ). As in other Mediterranean invertebrate benthic groups (Bianchi \& Morri 2000, Simboura \& Nicolaidou 2001, Cantone 2003), most syllid species belong to the Atlantic-Mediterranean category. When the different coastlines are examined, the latter remains clearly the most abundant category in Spain, North Western Italy, the North Adriatic and the Greek Aegean, while the eastern coasts, excluding the Greek one, show a progressive reversed trend of dominance between the Atlantic-Mediterranean and the cosmopolitan forms (Ionian Salento), with a near equivalence (Cyprus, Adriatic Salento) or a slight prevalence of this last category (Turkish Aegean), which becomes higher on the Israeli and Eastern Sicilian coasts. This pattern could be explained by a progressive reduction in the influence of waters from the Atlantic Ocean moving from the Strait of Gibraltar eastwards, but the northern Adriatic Sea and the Greek Aegean do not take part in the general pattern. Therefore, the distribution of syllids suggests the existence of an 'Atlantism' gradient, decreasing eastwards and corresponding to a temperature gradient when bioclimatic categories were analysed.

Analysis of the Apulian coast reveals some marked differences in category compositions between the northern and southern parts of the Adriatic Sea. The former confirms its North Atlantic affinity; in contrast both the coastlines of Salento show an eastern affinity (particularly with Cyprus and the Turkish Aegean).

The high percentages of amphi-Atlantic forms (especially from the Caribbean area) in the eastern sectors must also be taken into account.

\section{Cluster analysis}

The pattern derived by cluster analysis confirms the already observed affinities. Analysis of the similarity matrices shows, in general, the presence of 3 main groups that, from a bioclimatic point of view, should, respectively, represent warm (Israeli, Eastern Sicilian), temperate-warm (Ionian and Adriatic Salento, Cyprus, Turkish Aegean) and temperate (Spanish, North Western Italian) areas, separated from the colder areas (North Adriatic, Greek). These similarities may be indicative of the importance of environmental parameters in the distribution of Syllidae. For example, Bray-Curtis similarity coefficients indicate that the Greek Aegean is the most similar coastline to that of the North Adriatic, in faunistic (65.38) as well as bioclimatic (82.08) and biogeographical (91.25) analyses; this could, in part, be explained by the cooccurrence of similar ecological features (Arvanitidis et al. 2002). A faunistic affinity between these 2 sectors has already been hypothesized on the basis of the co-occurrence of some endemic polychaete species (Cantone 2003).

\section{Significance of grouping}

Comparisons between the 3 matrices derived from the original set of data reveal that the faunistic composition of each analysed Mediterranean coastline is not randomly organized. In fact, the significance of the high correlation between faunistic and bioclimatic similarity matrices (rho $=0.885$ ) supports the hypothesis that the syllid distributional pattern is due to a speciesassemblage rule linked to the general environmental conditions of a specific area (e.g. species belonging to colder categories distribute mainly along colder Mediterranean coastlines). Using the same statistical routine we similarly demonstrate the non-significance of the high correlation (rho $=0.813$ ) between faunistic and biogeographic similarity matrices, thus disproving the existence of a biogeographic distributional pattern of the Mediterranean syllids linked to some 'historical constraints'. In other words, the complex Mediterranean geological history does not seem to have influenced the present syllid distribution (e.g. AtlanticMediterranean species are not exclusively dominant along western coastlines; Indo-Mediterranean species have been recorded along Spanish, but not along Levant Sea coastlines). Such observations could be explained by the particular biology of these small polychaetes. Rapid life cycles and a dispersal capability due to the presence of planktonic reproductive stages in most of the species (San Martín 2003) may enable syllids to reach more suitable habitats. 


\section{BIOENV analysis}

Conclusions based on faunistic information have been confirmed by relating species distribution to several environmental parameters in the observed areas. Species distribution seems to be directly linked both to minimum and maximum mean annual temperature and salinity. However, an 'author effect' (Giangrande \& Licciano 2004) in the taxonomic updating of the analysed faunistic inventories must also be taken into consideration. The use of a relative parameter (T.U.I.) allows a kind of updating standardization of the analysed inventories, which, in turn, permits us to relate species distribution to environmental parameters, even in those analysed sectors suffering from a lack of recent research.

\section{Final remarks}

The Spanish sector is the one with the highest numbers of species and endemic forms; this is most probably due to the presence of the best laboratory for Syllidae in the world. Moreover, the unique presence of some Indo-Mediterranean species does not contradict San Martín's (1984) considerations about the faunistic affinity of this coastline to the Red Sea.

Furthermore, our understanding of the faunistic, biogeographic and bioclimatic compositions on the presently studied coastlines may change with the increase of taxonomic knowledge; many syllid species previously thought to have a worldwide distribution are probably complexes of sibling species with more restricted distributions (Martin et al. 2003).

As proposed by Bianchi (2004) based on the distribution of thermophilic species, our results support a subdivision of the Mediterranean Basin into northern and southern areas (rather than western and eastern), and enhance our ability to use syllids, not only in environmental impact studies, but also to describe different environmental conditions (Giangrande et al. 2004, Musco et al. 2004).

These results, coupled with the rapid life cycles and dispersal capability of syllids, support their use as indicators in assessing large-scale ecological changes, even over relatively short periods. A visual comparison between analysed inventories showed that more recently recorded Mediterranean syllids mainly belong to warmer categories, while some others previously recorded and mainly characteristic of temperate-cold areas were no longer mentioned in recent works (i.e. Exogone fauveli, E. brevipes, Autolytus alexandri, A. rubrovittatus, Paratyposyllis peresi, Salvatoria tenuicirrata). These preliminary observations could be due to the more southern locations of recent work carried out along Mediterranean coastlines, but do not exclude the possibility of a general 'tropicalization' trend of Mediterranean fauna (Bianchi 1997, Turley 1999, Grubelic et al. 2004).

This seems to be a good starting point for further investigations. As Syllidae were found to be good faunistic and ecological indicators of the physical environment, characterizing different areas inside the Mediterranean Sea, with the appropriate experimental design, they could possibly be utilized to describe large environmental changes in time.

Finally, the importance of taxonomy in the field of ecology and taxonomic re-evaluation should also be taken into account (Boero 2001, Giangrande 2003). The present results were obtained on the basis of good taxonomic resolution, as the family was well known from a taxonomic point of view and has been studied in depth by a great number of specialists around the world. Probably any group of organisms would be indicative if the analyses were conducted on a fine taxonomic scale.

Acknowledgements. We thank Dr. K. R. Clarke for his kindness and willingness to help us to statistically solve the tricky logical question of relating different matrices derived from the same dataset, and C. Arvanitidis and 2 anonymous reviewers for their helpful comments, which improved the manuscript considerably. We also thank F. Boero, S. Fraschetti and A. Terlizzi for stimulating discussions, and L. Stabili, M. Licciano, P. Guidetti, G. Guarnieri and P. D'Ambrosio for their helpful support. An affectionate thanks goes to $\mathrm{M}$. Tataranni from the University of Pisa for her helpful logical and practical suggestions. This study was financially supported by the FIRB project of MURST (Ministero dell'Università e della Ricerca Scientifica e Tecnologica) and the MARBEF Network of Excellence 'Marine Biodiversity and Ecosystem Functioning', which is funded in the Community's Sixth Framework Programme (Contract No. GOCE-CT-2003505446)

\section{LITERATURE CITED}

Arvanitidis C (2000) Polychaete fauna of the Aegean Sea: inventory and new information. Bull Mar Sci 66:73-96

Arvanitidis C, Bellan G, Drakopoulos P, Valavanis V, Dounas C, Koukouras A, Eleftheriou A (2002) Seascape biodiversity patterns along the Mediterranean and Black Sea: lessons from the biogeography of benthic polychaetes. Mar Ecol Prog Ser 244:139-152

Badalamenti F, Cantone G, Domina N, Di Pietro D, Catalano E, Mollica E, D'Anna G (1999) Primi dati sulla fauna a policheti di substrato duro dell'infralitorale fotofilo superiore. Biol Mar Mediterr 6:230-236

Banse K (1959) Über die Polychaeten-Besiedlung einiger submariner Höhlen. Ergebnisse der österreichischen Tyrrenian-Expedition 1952, Teil XII. Publ Stn Zool Napoli 30:417-469

Bellan G (1991) Inventaire de la faune des Annélides Polychètes de Méditerranée. Rapp Congr CIESM 32: 105-106 
Ben-Eliahu MN (1977a) Polychaete cryptofauna from rims of similar intertidal vermetid reefs on the Mediterranean coast of Israel and in the Gulf of Elat: Syllinae and Eusyllinae (Polychaeta: Errantia: Syllidae). Isr J Zool 26:1-58

Ben-Eliahu MN (1977b) Polychaete cryptofauna from rims of similar intertidal vermetid reefs on the Mediterranean coast of Israel and in the Gulf of Elat: Exogoninae and Autolytinae (Polychaeta: Errantia: Syllidae). Isr J Zool 26: 59-99

Ben-Ehliau MN (1995) A list of Polychaeta along the Levant coast. Haasiana 1:78-93

Ben-Ehliau MN, Fiege D (1995) Polychaeta from the continental shelf and slope of Israel collected by the 'Meteor' 5 Expedition (1987). Senckenb Marit 25(4/6):85-105

Bianchi CN (1997) Climate change and biological response in the marine benthos. In: Piccazzo M (ed) Atti del XII Congresso della Associazione Italiana di Oceanografia e Limnologia, Genova, 1:3-20

Bianchi CN (2004) Biodiversity issues for the next coming tropical Mediterranean Sea. Biol Mar Mediterr 11(3):4

Bianchi CN, Morri C (2000) Marine biodiversity of the Mediterranean Sea: situation, problems and prospects for future research. Mar Pollut Bull 40:367-376

Boero F (2001) Light after dark: the partnership for enhancing expertise in taxonomy. Trends Ecol Evol 16:226

Bouillon J, Medel MD, Pagès F, Gili J, Boero F, Gravili C (2004) Fauna of the Mediterranean Hydrozoa. Sci Mar 68(2):5-438

Cantone G (1971) Ricerche sulla fauna e sulla zoogeografia della Sicilia. LI. Ricerche sui policheti della Sicilia. Boll Accad Gioenia Sci Nat 10(4):914-944

Cantone G (2001) Fauna bentica dell'isola Lachea (Sicilia Orientale). Boll Accad Gioenia Sci Nat 34(360):49-64

Cantone G (2003) Distribution of benthic polychaetous annelids in the Adriatic Sea with zoogeographic considerations. Biogeographia 14:169-193

Cantone G, Fassari G (1980) Osservazioni sul popolamento polichetologico della penisola della Maddalena (Siracusa). Animalia 7(1/3):135-150

Cantone G, Fassari G, Brigandi S (1979) Ricerche sui policheti e molluschi di una grotta semisommersa del litorale catanese. Animalia 6(1/3):127-171

Cantone G, Catalano D, Di Pietro N, Fassari G, Mollica E, Scuderi D (2003) L'area marina protetta 'Isole Ciclopi': un forziere di biodiversità? Biol Mar Mediterr 10(2):25-33

Castelli A, Abbiati M, Badalamenti F, Bianchi CN and 8 others (1995) Annelida Polychaeta, Pogonophora, Echiura, Sipuncula. In: Minelli A, Ruffo S, La Posta S (eds) Checklist delle specie della fauna italiana, Vol 19. Calderini, Bologna, p 1-45

Çinar MH, Ergen Z (2002) Faunistic analysis of Syllidae (Polychaeta: Annelida) from the Aegean Sea. Cah Biol Mar 43: 171-176

Çinar MH, Ergen Z (2003) Eusylline and Syllinae (Annelida: Polychaeta) from northern Cyprus (eastern Mediterranean Sea) with a checklist of species reported from the Levant Sea. Bull Mar Sci 72(3):769-793

Çinar ME, Ergen Z, Benli HA (2003) Autolytinae and Exogoninae (Polychaeta: Syllidae) from northern Cyprus (eastern Mediterranean Sea) with a checklist of species reported from the Levant Sea. Bull Mar Sci 72(3):741-767

Clarke KR (1993) Non-parametric multivariate analyses of changes in community structure. Aust J Ecol 18:117-143

Coma R, Ribes M, Gili MJ, Zabala M (2000) Seasonality in benthic ecosystems. Trends Ecol Evol 15:448-453

Corriero G, Gherardi M, Giangrande A, Longo C, Mercurio M, Musco L, Nonnis Marzano C (2004) Inventory and dis- tribution of hard bottom fauna from the marine protected area of Porto Cesareo (Ionian Sea): Porifera and Polychaeta. Ital J Zool 71:237-245

Ergen Z, Çinar ME (1997) Polychaeta of Antalya Bay (Mediterranean coast of Turkey). Isr J Zool 43:229-241

Fauchald K (1984) Polychaete distribution patterns, or: Can animals with Paleozoic cousins show large-scale geographical patterns? In: Hutchings PA (ed) Proc 1st Int Polychaete Conf Sydney. The Linnean Society of New South Wales, Sydney, p 1-6

Fauvel P (1923) Polychètes errantes. Faune Fr 5:1-488

Fauvel P (1937) Les fonds de peche pres d'Alexandrie. XI. Annélides Polychètes. Notes et Mémoires. Direction des Recherches des Pêcheries, Le Caire, 19:191-160

Fauvel P (1955) Contribution a la faune des Annelides Polychètes des côtes d'Israel. Bull Sea Fish Res Stn Isr 10:3-12

Fauvel P (1957) Contribution a la faune des Annelides Polychètes des côtes d'Israel. Bull Sea Fish Res Stn Isr 6: 213-219

Fishelson L, Haran T (1986) Epifauna of algae on a rocky platform near Mikhmoret (Mediterranean Sea, Israel): composition and dynamics. Isr J Zool 34:105-123

Fraschetti S, Giangrande A, Terlizzi A, Della Tommasa L, Miglietta MP, Boero F (2002) Spatio-temporal variation of hydroids and polychaetes associated to Cystoseira amentacea (Fucales, Phaeophyceae): a regional scale approach. Mar Biol 140:949-957

Gherardi M, Lepore E, Sciscioli M (1993) Distribution of the polychaetous annelids in the Ionian and lower Adriatic Sea: descriptive analysis. Oebalia 19:27-45

Gherardi M, Giangrande A, Corriero G (2001) Epibiontic and endobiontic polychaetes of Geodia cydonium (Porifera, Demospongiae) from the Mediterranean Sea. Hydrobiologia 443:87-101

Giangrande A (2003) Biodiversity, conservation and the 'taxonomic impediment'. Aquat Conserv Mar Freshw Ecosyst 13:451-459

Giangrande A, Licciano M (2004) Factors influencing latitudinal pattern of biodiversity: an example using Sabellidae (Annelida, Polychaeta). Biodiversity Conserv 9(13): 1633-1646

Giangrande A, Montinaro P (1989) Sabellidae (Polychaeta) del Mediterraneo: la distribuzione delle specie è fortemente correlata a quella degli specialisti. Biol Mar Mediterr 6:216-220

Giangrande A, Delos AL, Fraschetti S, Musco L, Licciano M, Terlizzi A (2003) Polychaete assemblages along a rocky shore on the South Adriatic coast (Mediterranean Sea): patterns of spatial distribution. Mar Biol 143:1109-1116

Giangrande A, Delos AL, Musco L, Licciano M, Pierri C (2004) Polychaete assemblages of rocky shore along the South Adriatic coast (Mediterranean Sea). Cah Biol Mar 45: 85-95

Goren M (1979) Development of benthic community on artificial substratum at Ashdod (eastern Mediterranean). Oceanol Acta 1980:275-283

Grubelic I, Antolic B, Despalatovic M, Grbec B, Paklar GB (2004) Effect of climate fluctuations on the distribution of warm-water coral Astroides calycularis in the Adriatic Sea: new records and review. J Mar Biol Assoc UK 84: 599-602

Katzmann W (1972) Die Polychaeten Rovinnjs (Istrien/ Jugoslavien). Zool Anz 188(1/2):116-144

Laubier L (1966) Sur quelques annélides polychètes se la région de Beyrouth. Misc Pap Nat Sci Am Univ Beirut 5: $1-15$

Licher F (1999) Revision der Gattung Typosyllis Langerhans, 
1879 (Polychaeta: Syllidae). Morphologie, Taxonomie und Phylogenie. Abh Senckenb Naturforsch Ges 551:1-336

Marenzeller E (1874) Zur Kenntnis der adriatischen Anneliden. Sitzungsber K Akad Wiss Math Naturw C1 72: 129-171

Martin D, Britayev TA, San Martín G, Gil J (2003) Inter-population variability and character description in the sponge associated Haplosyllis spongicola complex. (Polychaeta: Syllidae). Hydrobiologia 496(1-3):145-162

Morri C, Bianchi CN, Cocito S, Peirano A and 7 others (1999) Biodiversity of marine sessile epifauna at an Aegean island subject to hydrothermal activity: Milos, eastern Mediterranean Sea. Mar Biol 135(4):729-739

Musco L, Cavallo A, Giangrande A (2004) I sillidi (Annelida, Polychaeta) del litorale brindisino: possibilita' di un loro impiego come indicatori di qualità dell'ambiente. Thalassia Salentina 27:161-174

Musco L, Çinar ME, Giangrande A (2005) A new species of Sphaerosyllis (Polychaeta: Syllidae: Exogoninae) from the coasts of Italy and Cyprus (eastern Mediterranean Sea). It J Zool 72:161-166

NAVOCEANO (US Naval Oceanographic Office) (1998) Global ocean profiles of salinity, temperature and sound velocity from the generalized digital environmental model (GDEM) of the US Naval Oceanographic Office. Oceanogr Lit Rev 45(3):606

Nogueira JM, San Martín G (2002) Species of Syllis Savigny in Lamarck, 1818 (Polychaeta: Syllidae) living in corals in the state of São Paulo, southeastern Brazil. Beaufortia 52(7):57-93

Parenzan P (1983) Puglia marittima. Congedo, Galatina

Pérès JM (1954) Contribution a l'etude des annèlides polychétes de la Mediterranée occidentale. Rec Trav Stat Mar Endoume 13(8):83-155

Pérès JM (1985) History of the Mediterranean biota and the colonization of the depths. In: Margalef R (ed) Key environments: western Mediterranean. Pergamon Press, Oxford, p 198-232

Editorial responsibility: Otto Kinne (Editor-in-Chief), Oldendorf/Luhe, Germany
Por FD (1978) Lessepsian migration. Ecological studies, Vol 23. Springer-Verlag, Berlin

Por FD (1989) The legacy of Thetys: an aquatic biogeography of the levant. Kluwer Academic Publishers, Dordrecht

Pozar-Domac A (1978) Catalogue of the Polychaetus annelids of the Adriatic Sea. Acta Adriat 19:1-59

San Martín G (1984) Biogeography of the Syllidae (Polychaeta) from the Spanish Mediterranean coasts. In: Hutchings PA (ed) Proc 1st Int Polychaete Conf. Sydney. The Linnean Society of New South Wales, Sydney, p 303-322

San Martín G (2003) Annelida, Polychaeta. II. Syllidae. In: Ramos MA, Tercedor JA, Bellés i Ros X and 6 others (eds) Fauna Iberica, Vol 21. Museo Nacional de Ciencias Naturales, CSIC, Madrid, p 1-554

Sarà M (1967) La zoogeografia marina e il litorale pugliese. Arch Bot Biogeogr Ital 43:321-327

Sardà R (1991) Polychaete communities related to plant covering in the mediolittoral and infralittoral zones of the Balearic Islands (western Mediterranean). PSZN I: Mar Ecol 12:341-360

Simboura N, Nicolaidou A (2001) The Polychaetes (Annelida, Polychaeta) of Greece: checklist, distribution and ecological characteristics. In: Monographs on marine sciences, Vol 4. National Centre for Marine Research, Athens, p 115

Somaschini A, San Martín G (1994) Description of two new species of Sphaerosyllis (Polychaeta: Syllidae: Exogoninae) and first report of Sphaerosyllis glandulata for the Mediterranean Sea. Cah Biol Mar 35:357-367

Somaschini A, San Martín G (1997) First report of Syllides articulosus (Polychaeta: Syllidae: Eusyllinae) for the Mediterranean Sea. Vie Milieu 47(3):267-271

Tena J, Capaccioni-Azzati R, Torres-Gravila FJ, Garcia-Carrascosa AM (2000) Polychaetes associated with different facies of the photophilic algal community in the Chafarinas arcipelago (SW Mediterranean). Bull Mar Sci 67(1): $55-72$

Turley CM (1999) The changing Mediterranean Sea-a sensitive ecosystem? Prog Oceanogr 4:387-400

Submitted: December 23, 2004; Accepted: June 28, 2005

Proofs received from author(s): November 4, 2005 